DOI 10.4467/2543733XSSB.17.010.7256

\title{
PAŃSTWA EUROPY ŚRODKOWEJ I ICH PRÓBY ZBLIŻENIA Z EWG PRZED 1989 R. ${ }^{1}$
}

Słowa kluczowe: Europa Środkowa, emigracja polityczna, stosunki Wschód-Zachód, integracja europejska

Stosunki Europy Wschodniej z EWG przed 1989 r. stanowiły jeden z elementów szerszej problematyki stosunków Wschód-Zachód. Rozwój restrykcyjnej polityki handlowej EWG coraz boleśniej dotykał kraje Europy Środkowej nie tylko z powodu ich sztywnej, niedostosowanej do gospodarki rynkowej specjalizacji gospodarczej. W okresie powojennym wszystkie kraje Europy Środkowej - każdy w różnym stopniu - przyjęły schemat rozwoju dający priorytet przemysłowi ciężkiemu kosztem pozostałych gałęzi gospodarki. W efekcie w chwili wzrostu dynamiki eksportu z krajów Europy Środkowej na rynki EWG, to jest w latach 60 . XX w., miały one do zaoferowania ograniczoną liczbę produktów przetworzonych, głównie artykułów przemysłu chemicznego, hutniczego, maszynowego i materiałów budowlanych, a listę zamykały surowce i produkty rolnicze. Socjalistyczna specjalizacja stała się jeszcze głębsza w latach 70. Wówczas to kraje Europy Wschodniej podejmowały chybione decyzje inwestycyjne, stawiając na produkty, na które malał światowy popyt (tekstylia, produkty przemysłu metalurgicznego, obuwie). Musiały przy tym zmagać się na rynkach EWG z rosnącą konkurencją innych państw uprzemysłowionych i protekcjonizmem Wspólnoty, usiłującej chronić swój restrukturyzujący się przemysł.

Stopniowa normalizacja stosunków Wschód-Zachód, która nastąpiła po zawarciu Aktu Końcowego KBWE w Helsinkach w 1975 r., stała się dla państw Europy Środkowej okazją do coraz śmielszych prób zbliżenia z Brukselą. Warto w tym kontekście przypomnieć, że część środowisk emigracji politycznej z Europy Środkowej już od końca lat 50. XX w. optowała za ostrożnym rozwojem współpracy między zachodnimi strukturami a krajami bloku komunistycznego.

${ }^{1}$ Badania, na których opiera się ten artykuł, zostały sfinansowane m.in. ze środków Narodowego Centrum Nauki, przyznanych na podstawie decyzji numer DEC-2013/08/M/HS3/00395. 


\section{Środowiska emigracji politycznej wobec idei współpracy gospodarczej Wspólnot Europejskich z państwami Europy Środkowej}

Dla działaczy emigracyjnych z Europy Środkowej istotną cezurą w ich poczynaniach politycznych stały się tzw. „odwilż” po śmierci Stalina oraz wydarzenia 1956 r. w Polsce i na Węgrzech. Kurczowe trzymanie się przeszłości i antykomunizmu spychało ich środowisko coraz wyraźniej na margines. Thomas Philippovich, węgierski przedstawiciel w Radzie Wolnej Młodzieży Europy Środkowo-Wschodniej, stwierdzał w Berlinie jesienią 1957 r., że rewolucja węgierska dowiodła, iż żelazna kurtyna to granica nietykalna i jedyne, na co pozostaje liczyć, to powolna i ograniczona ewolucja, która wprawdzie do upadku komunizmu nie doprowadzi, ale może w krótszej perspektywie przynieść polepszenie losu mieszkańców państw zza żelaznej kurtyny².

Po 1956 r. przedstawiciele większości środowisk emigracyjnych z Europy Środkowej wciąż konsekwentnie odrzucali pokusy definitywnego uznania podziału Europy ${ }^{3}$. W najbardziej radykalnej formie chodziło o kategoryczny sprzeciw wobec negocjacji czy projektów wielostronnych uregulowań utrwalających zniewolenie części jej narodów ${ }^{4}$. W 1964 r. Paul de Auer, wybitny węgierski działacz Ruchu Europejskiego i były minister pełnomocny Węgier we Francji, powoływał się na zapewnienia Lyndona Johnsona z grudnia 1963 r., że nie zostanie zawarty żaden układ utrwalający podział Niemiec: „Chcemy, by zasada ta była stosowana do całej Europy rozdzielonej żelazną kurtyną"5. Z kolei Assembly of Captive European Nations (ACEN) sprzeciwiało się w 1964 r. udzielaniu krajom satelickim ZSRR kredytów i żądało włączania kwestii praw człowieka do wszelkich rozmów o charakterze handlowym ${ }^{6}$.

Nie jest przesadą stwierdzenie, że wielu przedstawicieli emigracji miało ambiwalentny, by nie powiedzieć podejrzliwy stosunek do postępów zachodniej integracji, obawiając się tego, co Ruch Oporu Federalistów Węgierskich w liście z 13 listopada 1951 r. określił jako „Widmo całkowitego oddzielenia od reszty Europy”. W czerwcu 1953 r. na Europejskiej Konferencji Młodych w Paryżu, poświęconej problemom Europy Środkowo-Wschodniej, działacz Polskiego Ruchu Wolnościowego Niepodległość i Demokracja, Stanisław Grocholski, mówił, że obowiązkiem uchodźców jest pilnować, by europejska integracja w takim kształcie, w jakim się realizuje, nie przyniosła szkody idei integralności całej Europy ${ }^{8}$. Cztery lata później przedstawiciel Węgier, J. Sabados, stwierdzał, że postępy integracji zachodnioeuropejskiej nie sprzyjają dążeniom do osłabiania więzi ekonomicznych Europy

${ }^{2}$ T. Philip povich, Quelle politique serait susceptible de hâter le retour de conditions démocratiques en Europe de l'Est?, Que faire pour l'Europe de l'Est?, Session d'Etudes internationales, Berlin, 10-12 oct. 1957, supplément nr 30, „Jeunesse Libre”, s. 98-99.

${ }^{3}$ Mouvement européen, Commission des Pays de l'Europe centrale et de l'Est, tekst H. Macmillana z 25.10.1951, Historical Archives of the European Union (dalej HAEU), (Deposit Mouvement Européen, dalej ME), t. 2467.

4 Jeunesses européennes fédéralistes, Motion politique, Marienberg, le 01.09.53, HAEU, Deposit Walter Lipgens, t. 75.

5 Extraits d'autres interventions à la conférence, HAEU, (ME), t. 1613, s. 4.

${ }^{6}$ List Gustava F. Henyeya, przedstawiciela RFN w Assembly of Captive European Nations z 6 stycznia 1964 r., HAEU, (ME), t. 1613.

7 HAEU, (ME), 856/857.

${ }^{8}$ S. Grocholski, Les exilés et l'Europe, Paris 5-7/6/1953, HAEU, (ME), t. 1368, s. 7. 
Środkowej z Moskwą. Dlatego, jego zdaniem, by integracja europejska nie stała się celem samym w sobie, jej autorzy „muszą od samego początku funkcjonowania wspólnego organizmu zapewnić współpracę, tajną lub nie, krajów Europy Wschodniej”".

Przesłanki na rzecz przyszłej integracji całej Europy nie były nigdy li tylko natury kulturowej czy sentymentalnej, lecz również polityczno-gospodarczej ${ }^{10}$. Obie części kontynentu przedstawiano jako reprezentujące komplementarne typy gospodarki, odwołując się do słynnego rozróżnienia Francisa Delaisi’ego pomiędzy Europą konia pociągowego i Europą konia parowego ${ }^{11}$. Zdawano sobie jednak sprawę, że podział ten stanowił na przyszłość potencjalne źródło nierównowagi. Stąd rosnąca od lat 50. popularność opinii, że po wyzwoleniu Europy Wschodniej „niemożliwy będzie powrót do struktury wymiany, jaka istniała pomiędzy Wschodem a Zachodem przed wojną"" państw komunistycznych, przy wszystkich szkodach, jakie powoduje, wyrównuje szanse na późniejszą rekonwersję gospodarek zimnowojennych ${ }^{13}$.

Mniej więcej od połowy lat 50. powszechniejsze stawało się w Ruchu Europejskim i innych organizacjach skupiających emigrację stanowisko przychylne rozwojowi kontaktów z krajami bloku wschodniego. Już w grudniu 1954 r. Ladislas Bolgar w swoim raporcie na temat stosunków Wschód-Zachód konkluduje, że kraje zachodnie powinny ostrożnie sprzyjać rozwojowi wymiany handlowej z Europą Wschodnią celem podnoszenia poziomu życia jej mieszkańców, „o ile będzie temu towarzyszyć troska o respektowanie praw humanitarnych i moralnych" 14 . W późniejszych latach panowała zgoda, że kontakty, w tym kulturalne, są korzystne, bo niwelują skutki propagandy i poszerzają „strefę wolności”, przygotowując teren pod przyszłe działania ${ }^{15}$. Jak to ujął w $1964 \mathrm{r}$. Konrad Sieniewicz, Sekretarz Generalny Środkowoeuropejskiej Unii Chrześcijańsko-Demokratycznej, głównym zadaniem wymiany gospodarczej pomiędzy Wschodem a Zachodem miało być „przeciwdziałanie zupełnej integracji państw Europy Środkowej z gospodarką ZSRR oraz dostarczenie im alternatywy, która umożliwiłaby im rozwój ekonomiczny"16. Troska o podtrzymywanie wymiany handlowej Wschód-Zachód wynikała również z obawy, że towary z państw RWPG będą napotykały na coraz większe bariery taryfowe ze strony EWG.

Dodajmy, że w sytuacji doktrynalnego kryzysu komunizmu lat 60 . można było zauważyć w polityce państw Europy Środkowej liczne wyłomy. Polityka prowadzona przez te

9 J. S z a b a d o s, La Communauté économique européenne face au développement économique intervenu en Europe de l'Est, Berlin, 10-12.10.1957, supplément nr 30, Jeunesse Libre, s. 58-62.

${ }^{10}$ Por.: W. Prażuch, Środkowoeuropejska emigracja polityczna i jej wizje integracji kontynentu po upadku komunizmu w świetle dokumentów z Archiwów Historycznych Unii Europejskiej, [w:] A. Kozera, W. Prażuch, P. Szyja (red.), Polska, Europa Środkowa, Europa Zjednoczona: księga jubileuszowa dedykowana profesorowi Józefowi Łaptosowi, Wyd. Uniwersytetu Pedagogicznego, Kraków 2014, s. 352-364.

11 „Bulletin de Nouvelles Equipes Internationales”, nr 1/1949, s. 3-5. Por.: J. L a p to s, Europa jedna czy dwie? Projekty i koncepcje integracji europejskiej w latach 1944-1950, Oficyna Abrys, Kraków 1994, s. 104.

12 Wystąpienie André Philipa, przedstawiciela Francji przy Europejskiej Komisji Gospodarczej, 1964 r., HAEU, (ME), t. 1368, s. 7.

${ }^{13}$ Exposé M. Zaremby, HAEU, (ME), t. 1368, b.d., s. 2.

${ }^{14}$ L. Bolgar, Eléments du développement économique en Europe orientale, grudzień 1954, HAEU, (ME), t. 2147, s. 8 .

${ }_{15}$ Commission de l'Europe centrale et orientale, 21/6/1965, HAEU, (ME), t. 2458, s. 3-4.

${ }_{16}$ Compte rendu d'une conférence du ME organisée par la Commission de l'Europe centrale et orientale, HAEU, (ME), t. 1612, s. 22. 
kraje coraz częściej polegała na stosowaniu uników wobec moskiewskich dyrektyw i odwoływaniu się do pojęcia zysku ${ }^{17}$. Rosnące zróżnicowanie świata komunistycznego uznawano za korzystne, gdyż prowadziło do dezintegracji monolitu ${ }^{18}$. Zwracano zatem uwagę na konieczność zróżnicowanego podejścia do tych państw i unikania manichejskiej koncepcji, która kazałaby sądzić, że ideały humanizmu oraz demokracji są w sposób idealny realizowane na Zachodzie. 21 czerwca 1965 r. Komisja Środkowoeuropejska Ruchu Europejskiego opublikowała raport na temat polityczno-ekonomicznych stosunków Zachodu z Europą Wschodnią. Czytamy tam m.in., że kraje pozostające w okowach sowieckich nie powinny być traktowane jako satelickie, ale jako coraz bardziej niezależne ${ }^{19}$. Podstawowe założenie polegało na tym, by polityka zachodnia nie była przedmiotem ostentacyjnej koordynacji w ramach „wspólnego frontu”. Groziło to bowiem sprowokowaniem moskiewskiej centrali do zacieśniania socjalistycznej „,solidarności” i wymusiłoby analogiczne zachowania. Proponowaną alternatywą było cierpliwe wykorzystywanie naturalnych różnic interesów, pojawiających się w stosunkach pomiędzy krajami satelickimi a ZSRR, tak aby ich stopniowa emancypacja nie była odczuwana jako wymierzona przeciwko Moskwie. Postulaty te odnalazły częściowo odzwierciedlenie w polityce Wspólnot wobec członków Rady Wzajemnej Pomocy Gospodarczej.

\section{Symetria dwóch Europ?}

Próbując dokonać retrospektywnego spojrzenia na stosunki państw Europy Środkowej z EWG w okresie zimnowojennym, należy uwzględniać w analizie kraje, których przynależność do RWPG zaważyła na strukturze wymiany z krajami EWG, ale także na polityce handlowej Wspólnoty - nie tylko Polskę, Czechosłowację i Węgry, ale również Bułgarię, NRD i Rumunię. Stosunki gospodarcze pomiędzy Wspólnotą Europejską a państwami Europy Środkowej charakteryzowała od lat 50. XX wieku duża niestabilność, a na szczególne podkreślenie zasługuje tu dysproporcja między istniejącą wymianą handlową a brakiem jakichkolwiek ram instytucjonalnych ${ }^{20}$. Historycy dość zgodnie wyróżniają w tych stosunkach trzy etapy ${ }^{21}$ : fazę wrogości i nieuznawania istnienia EWG (1957-1971); etap realizmu (1972-1984), w którym nastąpiło pewne ocieplenie stosunków, i wreszcie etap współpracy (1985-1991 ${ }^{22}$. Integracja europejska, której początkiem

17 D. B o d e 1, La Communauté européenne et les pays de l'Est, Lausanne 1966, s. 7.

${ }^{18}$ Echanges commerciaux entre l'Est et l'Ouest. Opportunités et objectifs de ces échanges du point de vue des pays asservis, AS/SNR/ (6) 23, HAEU, Deposit Emile Noël, t. 1061, s. 6-7.

${ }^{19}$ Commission de l'Europe centrale et orientale, 21.06.1965, HAEU, (ME), t. 2147, s. 2.

${ }^{20} \mathrm{Na}$ temat związków EWG-RWPG szerzej: W. A n d r e ff, Les échanges commerciaux CE-CAEM: L'Europe de l'Est entre l'espoir et la peur, [w:] „, Regards sur l'actualité ", Paris, La Documentation française, 1990; M. Lavign e, Les relations économiques Est-Ouest, Presses Universitaires de France, Paryż 1979.

${ }^{21}$ Inną periodyzację stosunków EWG-RWPG podaje W. Andreff, dzieląc je na sześć faz: fazę konfrontacji (1958-1965), fazę zbliżenia (1965-1970), fazę dialogu (1970-1975), fazę rozbieżności (1975-1978), fazę negocjacji (1979-1985) oraz fazę wzajemnego uznania (1985-1991): W. A n d r e ff, Les rapports économiques entre les pays de la Communauté européenne et de l'Europe centrale depuis les années cinquante, [w:] L'Europe du centre. 50 années révolues, N. Bárdos-Féltoronyi, M. Sutton (red.), De Boeck Université, Bruxelles 1991, s. $168-169$.

${ }_{22}$ Patrz B. Pło n k a, Polityka Unii Europejskiej wobec Europy Środkowej, wyd. UJ, Kraków 2003, s. 26-31. 
było powstanie EWWiS, EWG i Euratomu, a także rosnący prestiż tych organizacji na arenie międzynarodowej przyjmowane były w Europie Wschodniej, a zwłaszcza w Moskwie, z irytacją. Dla ZSRR tworzenie Wspólnot było kolejną z zachodnioeuropejskich inicjatyw wpisujących się w kontekst zimnowojenny. W dniu 16 marca 1957 r. sowiecki MSZ przedłożył ambasadorom państw zachodnich notę, w której ZSRR ostrzegał przed konsekwencjami tworzenia Wspólnego Rynku. EWG została uznana za ekonomiczny fundament NATO, przejaw odrodzenia niemieckiego militaryzmu i gospodarczy eksperyment pełen sprzeczności właściwych kapitalizmowi, a przez to pozbawiony perspektyw. Stanowisko to przedstawiono wyczerpująco w dokumencie Instytutu Gospodarki Światowej i Stosunków Międzynarodowych, zatytułowanym XVII tez o Wspólnym Rynku. Polityka wschodniego mocarstwa sprowadzała się odtąd do prawnego i politycznego nieuznawania EWG oraz nieprzyjmowania do wiadomości transferu kompetencji na poziom ponadnarodowy. O ile Rada Wspólnot jako organ reprezentujący rządy państw członkowskich była de facto uznawana za partnera do rozmów, o tyle konsekwentnie ignorowano Komisję, preferując kontakty bilateralne. Jean Rey z Komisji EWG konstatował w 1964 r., że prowadzi to do kuriozalnych sytuacji: strona sowiecka domagała się przykładowo negocjowania preferencji celnych w stosunkach z Francją i RFN w czasie, gdy funkcjonowała już tylko taryfa wspólnotowa, a jedyną instancją upoważnioną do jej negocjowania była ignorowana przez Moskwę Bruksela ${ }^{23}$. ZSRR, który nie miał przy EWG swego przedstawiciela, złagodził swoje stanowisko dopiero w styczniu 1972 r., gdy Leonid Breżniew oznajmił, że EWG stanowi fragment rzeczywistości Zachodu, dając tym samym do zrozumienia, że możliwe staje się ułożenie stosunków ze Wspólnym Rynkiem. Decyzja ta dyktowana była względami ekonomicznymi, w tym rozwojem polityk wspólnotowych, lecz umożliwiły ją przede wszystkim postępy niemieckiej „Ostpolitik” Willy’ego Brandta oraz odprężenie związane z procesem helsińskim. Wkrótce potem Związek Radziecki podjął inicjatywy zachęcające do współpracy na linii EWG-RWPG. W swym programie z 1976 r. RWPG zamierzała negocjować z EWG jak wspólnota ze wspólnotą, co, rzecz jasna, nie mogło spotkać się z akceptacją ${ }^{24}$. Wspólnota nie chciała kupować sobie w ten sposób uznania ze strony Moskwy, tym bardziej że równorzędne traktowanie obu ugrupowań gospodarczych skazywałoby kraje bloku wschodniego na układanie stosunków z EWG za pośrednictwem zdominowanych przez Moskwę struktur.

Powołanie do życia RWPG było, by użyć stwierdzenia Gérarda Souliera, „konkretyzacją symetrii dwóch Europ" epoki zimnej wojny na płaszczyźnie ekonomicznej ${ }^{25}$. Organizacja powstała 25 stycznia 1949 r. w odpowiedzi na wcześniejsze o rok utworzenie OECD (16 kwietnia 1948 r.), choć jej status podano do publicznej wiadomości dopiero dziesięć lat później, 14 listopada 1959 r. Działalność Rady rozwinęła się stopniowo w dwóch kierunkach: wzmocnionej koordynacji prowadzącej niekiedy do wspólnych przedsięwzięć (ujednolicenie systemów przesyłania energii elektrycznej, powstanie rurociągu „Przyjaźń” itp.) oraz rosnącej specjalizacji, opartej na tzw. „socjalistycznym podziale pracy”. Zbiurokratyzowana struktura, którą cechował prymat czynnika ideologicznego, nie stała

${ }^{23}$ Conférence sur 1'Europe centrale et orientale, Bruxelles, 10-11.01.1964, wystąpienie Jeana Reya, HAEU, (ME), t. 1612, s. 3.

${ }^{24}$ M. Vill a n i, La politique de la Communauté européenne vers la Pologne et la Hongrie, Instituto di Studi Europei 'Alcide de Gasperi', anno academico 1988-1989.

${ }_{25}$ G. S o uli e r, L'Europe, Wyd. Armand Colin, Paryż 1994, s. 375. 
się nigdy rzeczywistym czynnikiem integrującym, ani w sferze gospodarczej, ani instytucjonalnej; nie stanowiła wspólnego rynku, ani nawet strefy wolnego handlu. Służyła bardziej koordynacji quasi-autarkicznych gospodarek państw członkowskich, których cechą była struktura ekonomiczna oparta na komplementarności wobec centrum, a konkurencyjności wobec siebie ${ }^{26}$. W tym monocentrycznym układzie główną rolę odgrywał Związek Radziecki, dostawca surowców, w tym paliw i ciężkiej technologii, oraz „odbiorca wyrobów wyższego stopnia przetwórstwa"27. Proces specjalizacji gospodarczej pod dyktando sowieckie napotykał zresztą niejednokrotnie na odruchy oporu ze strony krajów satelickich ${ }^{28}$.

\section{Faza nieuznawania - pierwsze próby zbliżenia}

Przez cały okres zimnej wojny stosunki Wspólnoty Europejskiej z krajami RWPG zależnymi od Moskwy utrudnione były przez doktrynalną postawę ZSRR. Kraje te, zmuszone prowadzić politykę zbieżną z polityką centrali, w miarę upływu lat coraz częściej dochodziły do wniosku, że w ich żywotnym interesie leży nawiązanie bezpośrednich kontaktów z Brukselą. Na ich politykę wpływał w tym względzie splot czynników, z których najważniejszymi były intensywność wymiany z EWG, stopień uległości wobec ZSRR i sposób pojmowania roli RWPG. Już w latach 60. państwa bloku wschodniego stanowiły dla Europy Zachodniej interesujące rynki zbytu. Eksportowano tu głównie towary pochodzenia przemysłowego, w tym zaawansowane technologicznie, o ile nie były wpisane na listę COCOM, czyli Komitetu Koordynacyjnego Wielostronnej Kontroli Eksportu ${ }^{29}$, dobra konsumpcyjne i produkty rolne (zboże). Z kolei kraje Europy Środkowo-Wschodniej sprzedawały na rynki EWG surowce, towary niskoprzetworzone, w ramach kontyngentów ilościowych określanych przez państwa członkowskie. Jedną z głównych przeszkód w handlu stanowił zaś brak wymienialności walut bloku wschodniego i kłopoty z uzyskaniem niezbędnej ilości dewiz. Z jednej strony zatem rozwijał się stopniowo system handlu wymiennego (barterowego), z drugiej zaś państwa członkowskie EWG udzielały wschodnioeuropejskim partnerom kredytów, powiększając ich zadłużenie zagraniczne.

W latach 1959-1970, gdy EWG znajdowała się w fazie przejściowej, nie istniała żadna wspólna strategia wobec państw zza żelaznej kurtyny. Kraje członkowskie stosowały wobec partnerów z Europy Wschodniej - ze względów doktrynalnych traktowanych jako kraje pozbawione gospodarki rynkowej - tak zwane kontyngenty importowe, gdyż

${ }^{26}$ Por. D. S i dja ns ki, Le dialogue des deux Europes et le rôle de la Communauté européenne, [w:] Un défi pour la Communauté européenne. Les bouleversements à l'Est et au Sud du continent, Université de Bruxelles, Bruxelles 1991.

${ }_{27}$ Biała Księga, Polska-Unia Europejska, Wspólpraca w ramach Grupy Wyszehradzkiej, Opracowania i Analizy, URM, Zeszyt 35, Warszawa 1993, s. 9.

${ }_{28}$ Rumunia wyrażała obawę, żeby kraje słabiej rozwinięte nie stały się wyłącznie dostarczycielami surowców. Por. F. Gołe mb s k i, Polska a zmiany zachodzące w państwach Europy Środkowo-Wschodniej i PoŁudniowo-Wschodniej, PISM, Warszawa 1990, s. 32.

${ }^{29}$ COCOM (Coordinating Committee for Multilateral Export Controls, pl. Komitet Koordynacyjny Wielostronnej Kontroli Eksportu) funkcjonował od 1949 do 1995 r. i skupiał 17 państw zachodnich. Miał za zadanie nie dopuścić do uzyskania przez kraje bloku wschodniego najnowocześniejszych technologii tzw. ,podwójnego zastosowania". 
większość państw komunistycznych nie należała do GATT (z wyjątkiem Czechosłowacji, członka założyciela GATT, oraz Polski i Węgier, mających status obserwatorów). Stanowisko EWG wobec państw o gospodarce centralnie sterowanej wynikało z art. 111 i 113 traktatu rzymskiego, określających kompetencje handlowe Wspólnoty wobec państw trzecich. Wprowadzanie w stosunku do państw Europy Środkowo-Wschodniej postanowień wspólnej polityki handlowej spotykało się zresztą z niechęcią państw członkowskich, bo oznaczało ograniczenie ich „suwerenności”. Do końca 1969 r. kraje członkowskie EWG zachowały prerogatywy w kwestii dwustronnych umów handlowych, w tym umów z państwami z Europy Wschodniej (pierwsze umowy tego rodzaju zawarto w 1959 r.). Od stycznia 1970 r., w świetle artykułu 113 traktatu rzymskiego, kompetencje w kwestii negocjowania podobnych umów miano przenieść na poziom wspólnotowy. Niektóre kraje członkowskie uprzedzająco odnowiły zatem przed końcem 1969 r. zawarte wcześniej porozumienia, w związku z czym Rada Wspólnoty postanowiła wprowadzić nowy okres przejściowy, trwający do 31 grudnia 1972 r. Począwszy od 1 stycznia 1973 r., żaden kraj członkowski EWG nie mógł już ani negocjować, ani podpisywać dwustronnych umów handlowych z państwami zza żelaznej kurtyny. 22 lipca 1974 r. Wspólnota podjęła decyzję o wprowadzeniu procedury informowania instancji w Brukseli w przypadku zamiarów zawarcia umów o współpracy, dzięki którym kraje członkowskie próbowały obchodzić regulacje dotyczące wspólnej polityki handlowej ${ }^{30}$. Procedura ta nie była zresztą łatwa w egzekwowaniu, skoro w interesie niektórych krajów leżało zachowanie większej swobody, choćby w udzielaniu krajom Europy Środkowo-Wschodniej kredytów.

Przykład Polski dobrze ilustruje, w jaki sposób państwa bloku wschodniego starały się obchodzić wynikający z imperatywów sowieckiej polityki nieformalny zakaz bezpośrednich kontaktów z Brukselą. Od 1 lipca 1962 r. 32\% polskiego eksportu na rynki krajów EWG stało się przedmiotem regulacji Wspólnej Polityki Rolnej. W efekcie eksport ten zanotował radykalny spadek. Chcąc temu zaradzić, Polska jako pierwszy kraj regionu nawiązała w 1965 r. dwustronne kontakty z Komisją. Wymiana listów pomiędzy Warszawą a Brukselą odbywała się pod pretekstem przystąpienia Polski do GATT, za pośrednictwem przedstawicieli EWG i Polski przy GATT w Genewie ${ }^{31}$. Podobnie krętymi ścieżkami wędrowała korespondencja dyplomatyczna dotycząca rozmaitych uzgodnień w sprawach rolnych i przemysłowych pomiędzy Brukselą a pozostałymi krajami Europy Środkowo-Wschodniej. Pierwsze kontakty Węgier z EWG miały miejsce w 1968 r., gdy podjęto pierwsze próby współpracy w dziedzinie handlu. Węgry jako drugi kraj Europy Środkowej doszedł w 1968 r. z Brukselą do porozumienia w sprawie eksportu wieprzowiny na rynki Wspólnoty. Polska w tym czasie miała już trzy takie umowy. Rumunia nawiązała kontakty ze Wspólnotą w 1969 r., Bułgaria w 1971 r., natomiast Czechosłowacja czekała z tym aż do 1978 r., kiedy to przystąpiono do rozmów z EWG w sprawie hutnictwa. Rozpoczęły się one dla niepoznaki w Genewie, dopiero później zostały przeniesione do Brukseli pod szyldem dyskusji ekspertów. W 1968 r. premier Węgier, Jenő Fock, stwierdził, co następuje:

30 Journal Officiel (JOCE) nr L. 208, 30.07.1974.

31 L. Kaw a n, Conséquences des modifications survenues en Hongrie sur les relations avec la Communauté européenne, [w:] Un défi pour la Communauté européenne. Les bouleversements à l'Est et au centre du continent..., s. 62. 
Zawsze byliśmy realistami i dlatego musimy uznać istnienie Wspólnego Rynku. Jeżeli nasze stosunki handlowe wymagać będą, abyśmy udali się do jednego z biur w Brukseli, nie uznamy tego za rezygnację z naszych zasad ${ }^{32}$.

Niewiele później, bo w grudniu 1970 r., sekretarz węgierskiego Komitetu Centralnego, Rezsö Nyers, zaznaczył, że Węgry prowadzą negocjacje z organami Wspólnoty, aby położyć kres niekorzystnej sytuacji dla węgierskiego eksportu żywności ${ }^{33}$. Jeśli chodzi o Rumunię, już od 1972 r. jej władze prowadziły wobec EWG quasi-niezależną politykę, a w 1976 r. Nicolae Ceauşescu zaprosił nawet wiceprzewodniczącego Komisji Europejskiej Christophera Soamesa do Bukaresztu.

Jak wynika z poniższej tabeli, w fazie największej wrogości w stosunkach dyplomatycznych, która miała miejsce po utworzeniu EWG (lata 1958-1965), nastąpił paradoksalnie dynamiczny wzrost wymiany handlowej. Niezależnie od oficjalnego stanowiska Moskwy, kraje Europy Środkowo-Wschodniej potrzebowały bowiem nie tylko dewiz i zachodnioeuropejskich towarów, ale również technologii.

Wymiana handlowa pomiędzy sześcioma krajami Europy Środkowo-Wschodniej (Polska, Węgry, Czechosłowacja, NRD, Rumunia i Bułgaria) a państwami EWG (w mln ecu)

\begin{tabular}{|c|c|c|c|}
\hline Lata & $\begin{array}{c}\text { Eksport z krajów } \\
\text { EŚ-W do EWG }\end{array}$ & $\begin{array}{c}\text { Import z EWG do } \\
\text { krajów EŚ-W }\end{array}$ & Bilans handlowy EWG \\
\hline 1958 & 609 & 550 & -59 \\
\hline 1963 & 1123 & 1003 & -120 \\
\hline 1965 & 1436 & 1386 & -50 \\
\hline 1968 & 1695 & 1946 & 251 \\
\hline 1973 & 3747 & 4447 & 700 \\
\hline 1975 & 5077 & 7119 & 2042 \\
\hline 1977 & 6580 & 7784 & 1204 \\
\hline 1979 & 8307 & 8836 & 529 \\
\hline 1981 & 9091 & 9846 & -1164 \\
\hline 1982 & 9734 & 8570 & -1679 \\
\hline 1983 & 10271 & 8592 & -3285 \\
\hline 1984 & 12943 & 9658 & -2772 \\
\hline 1985 & 13802 & 11030 & -1323 \\
\hline 1987 & 11351 & 10028 & -1263 \\
\hline 1988 & 11896 & 10633 & \\
\hline
\end{tabular}

źródło: EUROSTAT

${ }^{32} \mathrm{~L}$. Kaw a n, Les relations diplomatiques entre la communauté européenne et les pays de l'Europe centrale depuis les années cinquante, [w:] L'Europe du centre. 50 années révolues..., s. 157.

33 Ibidem, s. 158. 
Innym zjawiskiem było wyraźne spowolnienie dynamiki eksportu z Europy Środkowej w latach 1975-1978, co należy przypisać nie tylko początkom kryzysu gospodarczego w Europie Środkowej i Wschodniej, ale przede wszystkim wprowadzeniu przez EWG wspólnej polityki handlowej i rolnej ${ }^{34}$.

\section{Etap realizmu i wspólpracy}

Należy pamiętać, że już w 1963 r. w aide-mémoire adresowanym do ZSRR Wspólnota wyrażała nadzieję na normalizację stosunków pomiędzy dwoma ugrupowaniami gospodarczymi. W maju 1974 r. Rada Wspólnot wystosowała memorandum, w którym deklarowała gotowość do negocjacji w sprawie zawierania dwustronnych układów handlowych z krajami Europy Wschodniej i proponowała schemat umowy handlowej zawierający klauzulę najwyższego uprzywilejowania. Jednak ograniczenia ilościowe, wynikające z proponowanej umowy, w wielu przypadkach były mniej korzystne niż te stosowane wcześniej na mocy umów dwustronnych ${ }^{35}$. Nic dziwnego zatem, że schemat ten został przez kraje Europy Środkowo-Wschodniej odrzucony, nie licząc Rumunii, która ofertę przyjęła, a w 1980 r. podpisała ze Wspólnotą umowę handlową. W odpowiedzi na inicjatywę strony wspólnotowej we wrześniu 1974 r. sekretariat RWPG zaprosił przewodniczącego Komisji Wspólnot François-Xavier Ortoliego do Moskwy, celem przedyskutowania stosunków pomiędzy obiema organizacjami ${ }^{36}$. W 1975 r. w Moskwie odbyło się spotkanie ekspertów. Jak się jednak okazało, stanowisko RWPG, przesłane 16 stycznia 1975 r. przewodniczącemu Rady Europejskiej w formie projektu umowy, kolejny raz ignorowało transfer kompetencji na poziom wspólnotowy, w gruncie rzeczy proponując jedynie podpisanie szerokiej umowy z RWPG, jeśli pominąć nieliczne uzgodnienia o charakterze branżowym, co do których dopuszczalne byłyby uzgodnienia dwustronne ${ }^{37}$. Propozycja przyznawała RWPG kompetencje, których organizacja ta de facto nie miała, zważywszy, że RWPG nie wypracowała instrumentów wspólnej polityki handlowej ${ }^{38}$. Projekt, przewidujący także powstanie mieszanej komisji nadzorującej całokształt stosunków gospodarczych pomiędzy krajami członkowskimi EWG i RWPG, odrzucono jako niedopuszczalny i pozostający w sprzeczności z zasadami Wspólnoty. Wykładnia polityki Wspólnoty wobec Europy Środkowo-Wschodniej była bowiem niezmienna aż do 1988 r. i w znacznej mierze zbieżna z przedstawionymi wyżej postulatami emigracji politycznej: EWG upierała się przy uruchomieniu dwóch równoległych pro-

34 W. A n d reff, Les rapports économiques entre les pays de la Communauté européenne et de l'Europe centrale depuis les années cinquante..., s. 171.

35 Ibidem, s. 174.

${ }^{36}$ Węgry były członkiem GATT od 1973 r. i ramy wielostronne, czyli negocjacje EWG-RWPG, były dla nich bardziej korzystne. Umowa dwustronna nie znosiła ograniczeń importowych ze strony EWG. Po wejściu Grecji do EWG, Węgry na forum GATT domagały się zrekompensowania im wynikłych z tego strat.

${ }^{37}$ Por.: B. Christin e-Ry b a, L'Union européenne et l'Europe de l'Est. L'Evolution des relations de la Communauté - devenue Union européenne - avec l'Europe de l'Est et les perspectives d'avenir, „Revue du Marché Commun et de l'Union Européenne", nr 382, listopad 1994, s. 564-582.

${ }^{38} \mathrm{~L}$. Kaw a n, Les relations diplomatiques entre la communauté européenne et les pays de l'Europe centrale depuis les années cinquante..., s. 157. 
cesów, które w zamierzeniu miały pozwolić na stopniową emancypację państw satelickich spod moskiewskiej kurateli. Chodziło o zawieranie umów handlowych z każdym z krajów Europy Środkowo-Wschodniej z osobna i ograniczanie stosunków z RWPG do wymiany informacji w dziedzinach, w których obie organizacje prowadziły działalność charakteryzującą się interesem wspólnym.

W 1979 r. kompetencje Wspólnoty w dziedzinie handlu uległy wzmocnieniu. Ograniczono też możliwości odstępowania przez kraje członkowskie od kontyngentów importowych. Z czasem w krajach satelickich zaczęto coraz częściej skrycie odchodzić od linii politycznej narzuconej przez ZSRR. Począwszy od 1976 r., EWG zdołała skłonić kraje Europy Środkowo-Wschodniej, z wyjątkiem NRD, do podpisania branżowych umów na produkty przemysłu hutniczego (1978-1979, wznowione w 1983 r.). Jako członkowie lub obserwatorzy GATT poszły one za przykładem Rumunii, podpisując także umowy dotyczące przemysłu tekstylnego ${ }^{39}$, zaś sama Rumunia - jako prekursor - posunęła się w 1980 r. dalej, zawierając z EWG umowę o współpracy, do której dołączono część handlową, ograniczoną do artykułów przemysłowych. Co ważne, umowa przewidywała powołanie Komisji mieszanej szczebla ministerialnego ${ }^{40}$. Dzięki skromnym koncesjom ze strony EWG umowa ta dawała Rumunii przewagę konkurencyjną w stosunku do pozostałych krajów Europy Środkowo-Wschodniej, nieposiadających takiej umowy. Jeżeli do wspomnianych umów ograniczających de facto możliwości eksportowe Europy Środkowo-Wschodniej dodać efekt wspólnotowego protekcjonizmu, wynikającego z założeń Wspólnej Polityki Rolnej (WPR), nie dziwi stagnacja środkowoeuropejskiego eksportu na rynki EWG w końcu lat 70. Regulacje WPR dotykały w 1975 r., w zależności od kraju, od 7,7\% do 39\% ich eksportu produktów rolnych do $\mathrm{EWG}^{41}$. Krajem, który najsilniej odczuł wynikające ze WPR ograniczenia, były Węgry (eksporter mięsa wołowego), jako że ich eksport do EWG spadł w latach 1975-1983 z 36 do 27\% ogółu węgierskiego ekspor$t^{42}$. Także duża część eksportu produktów przemysłowych z państw Europy Środkowo-Wschodniej do EWG podlegała ograniczeniom ilościowym. Tytułem przykładu, w latach 1980-1986, przy ogólnym wzroście wspólnotowego importu produktów przemysłu hutniczego o 7,7\%, węgierski eksport stali i żelaza do EWG zmalał o 25,9\%. Udział państw Europy Środkowej w imporcie produktów tekstylnych z krajów członkowskich EWG spadł zo 3\% na skutek przystąpienia do umów AMF I - AMF IV.

Zawieranie ograniczonych umów branżowych w różnych sprawach było sposobem na zachowanie pozorów trzymania się oficjalnej linii politycznej. Od roku 1983 r. Węgry usiłowały wysondować możliwości zawarcia klasycznej już umowy handlowej z EWG, tym bardziej że od szczytu grupy G7 w Wersalu w czerwcu 1982 r. oraz szczytu w Waszyngtonie w listopadzie tego samego roku Zachód skłonny był traktować państwa so-

39 Odnośnie do tekstyliów chodziło o umowy AMF I (1976, Rumunia), AMF II (Rumunia - 1977, Węgry 1978, Polska i Bułgaria - 1979), AMF III (1982) oraz AMF IV (1986).

${ }^{40}$ Realizacja postanowień umowy stanęła pod znakiem zapytania w 1982 r. na skutek rumuńskiej polityki handlowej, kładącej nacisk na eksport za wszelką cenę. Po wygaśnięciu umowy jej przedłużenie zablokowano z powodu łamania praw człowieka w Rumunii. Wspólnota uczyniła z zawieszenia negocjacji, otwartych w marcu 1989 r., element nacisku na władze w Bukareszcie.

${ }^{41} \mathrm{~W}$. A n d reff, Les rapports économiques entre les pays de la Communauté européenne et de l'Europe centrale depuis les années cinquante..., s. 175.

$42 \mathrm{Na}$ podstawie wyliczeń A. Inotai opartych na danych OECD. 
cjalistyczne w sposób zróżnicowany, a w każdym razie odmienny niż ZSRR ${ }^{43}$. Węgry, które niedawno zainicjowały ograniczone reformy gospodarcze, nie chciały dłużej być traktowane jako kraj o gospodarce państwowej i centralnie sterowanej, podlegający ograniczeniom ilościowym. Być może pragnienie wyjścia $\mathrm{z}$ tej kategorii państw wiązało się z dalekosiężną strategią, której celem miało być osiągnięcie układu stowarzyszeniowego typu jugosłowiańskiego ${ }^{44}$. W 1982 r. rząd węgierski wyraził intencję zawarcia z EWG dwustronnej umowy handlowej, oczekując od strony wspólnotowej usunięcia wszelkich ograniczeń w imporcie węgierskich towarów, a przynajmniej ustalenia kalendarza ich likwidacji. Węgrzy odnosili się zresztą krytycznie do rumuńskich ustępstw zawartych w umowie o wymianie towarów przemysłowych z 1980 r., stanowiących - ich zdaniem niekorzystny precedens dla innych państw regionu. Budapeszt powoływał się przy tym na art. 4 GATT, który zakładał wzajemne znoszenie ograniczeń ilościowych. EWG pragnęła wesprzeć proces węgierskich reform, lecz spełnienie wygórowanych oczekiwań Budapesztu mogło być uznane za niebezpieczny precedens w stosunku do pozostałych krajów Europy Środkowo-Wschodniej. Wobec niezdecydowania Wspólnoty Węgry czasowo wstrzymały rozmowy, aby podjąć je na nowo dopiero w nowym kontekście politycznym powstałym po $1985 \mathrm{r}$.

\section{Okres pieriestrojki - normalizacja stosunków}

Wraz z nastaniem pieriestrojki przed stolicami państw Europy Środkowej otwarła się możliwość samodzielnego układania sobie relacji z EWG. Pierwsza deklaracja o gotowości do normalizacji stosunków wyszła z ust Michaiła Gorbaczowa w Moskwie w maju 1985 r., podczas rozmów z włoskim premierem i przewodniczącym pracom Rady Wspólnot, Bettino Craxim. Nowy gensek czynił wówczas aluzje do możliwości współpracy RWPG ze Wspólnotą jako organizmem politycznym. ZSRR porzucił tym samym koncepcję umowy handlowej EWG-RWPG, proponując w zamian krótką deklarację o nawiązaniu stosunków, których zakres i treść pozostawały do późniejszego ustalenia. W dniu 14 czerwca 1985 r. sekretarz RWPG, Wiaczesław Syczow, wystosował do Jacques'a Delorsa, za pośrednictwem polskiego ambasadora w Belgii Stanisława Matoska, list z propozycją wspólnej deklaracji. 30 czerwca 1985 r. Willy de Clercq przekazał ambasadorowi Rumunii odpowiedź, w której Wspólnota wyrażała gotowość do podjęcia przerwanego w 1981 r. dialogu z RWPG ${ }^{45}$. W 1986 r. RWPG przystała na podejście równoległe (z jednej strony EWG-RWPG, z drugiej zaś EWG - państwa członkowskie RWPG). Po spotkaniach ekspertów, które odbyły się w Genewie, 8 czerwca 1988 r. w Berlinie parafowano Wspólną Deklarację, podpisaną ostatecznie w Luksemburgu 25 czerwca tego roku. Tym

${ }^{43}$ Por.: R. Mate ra, Stosunek Grupy Siedmiu do Europy Środkowej i Wschodniej w okresie zimnej wojny oraz $w$ czasie transformacji ustrojowej, „Studia Europejskie”, 2008/1, s. 52-53.

${ }^{44}$ Układ kooperacyjny z Jugosławią, zawarty w dniu 25 lutego 1980 r., był w pewnym sensie pionierem późniejszych „układów europejskich” z lat 90. XX w. Por. Z. Vučk ović, Kontakty gospodarcze wspólnot europejskich z SFR Jugosławia (1968-1991), „Zeszyty Naukowe Towarzystwa Doktorantów UJ”, Nauki Społeczne, $\operatorname{Nr} 6$ (1/2013), s. 47-48.

${ }_{45} \mathrm{P}$. D e $1 \mathrm{w}$ i t, Historique des relations entre la Communauté et les pays de l'Europe centrale et orientale, [w:] Un défi pour la communauté européenne. Les bouleversements à l'Est et au centre du continent..., s. 11. 
samym EWG i RWPG nawiązały ze sobą oficjalne stosunki, lecz EWG nie zgodziła się na nadanie im formy traktatowej ${ }^{46}$. Traktaty miały być natomiast zawierane między EWG a poszczególnymi państwami Europy Wschodniej. Wspólna Deklaracja stała się cezurą w historii kontaktów pomiędzy integrującą się Europą Zachodnią a obozem realnego socjalizmu; niemniej była bardziej wyrazem politycznego otwarcia na Zachód niż zrozumienia ekonomicznych implikacji integracji.

Krótko po podpisaniu deklaracji większość państw Europy Środkowo-Wschodniej, oprócz Rumunii, otwarła przedstawicielstwa dyplomatyczne przy Wspólnotach. Między listopadem 1988 r. a czerwcem 1990 r. EWG i RWPG odbyły cztery spotkania robocze dla określenia dziedzin przyszłej współpracy (np. w ochronie środowiska ${ }^{47}$. Wykorzystując ewolucję sytuacji politycznej w Europie Środkowej, strona wspólnotowa mogła realizować swoją tradycyjną politykę polegającą na zapewnieniu krajom Europy Środkowo-Wschodniej prawa do samodzielnego negocjowania umów. Jednocześnie dostosowywała własne instrumenty prawne i ekonomiczne do sytuacji w poszczególnych krajach bloku, kierując się dwoma kryteriami, będącymi odtąd stałymi „elementami doktryny określającej jej stosunki z otoczeniem”, czyli tzw. conditionnalité (warunkowością) oraz specyfiką każdego z nich ${ }^{48}$.

Od czasu likwidacji socjalistycznych ram, które do końca 1990 r. określały warunki wzajemnej wymiany, stosunki handlowe w obrębie RWPG uległy gwałtownej dezorganizacji. Arbitralny charakter rozliczeń, opartych na sztucznym kursie rubla transferowego, uniemożliwiał wszelki rachunek ekonomiczny. Propozycje dotyczące wymienialności, zarówno wysunięta przez Polskę w latach 60 ., by dłużnik spłacał część zobowiązań w walucie wymienialnej, jak i jej nowa wersja, zaproponowana przez Węgry w 1987 r., nie miały szans powodzenia, ponieważ wszelkie radykalne pociągnięcia były niekorzystne dla największego z dłużników, jakim był ZSRR. Oznaczało to, że przedsiębiorstwa, których rola $\mathrm{w}$ wymianie handlowej miała rosnąć, pozbawione były podstawowego narzędzia, niezbędnego w podejmowaniu decyzji gospodarczych.

Dawniej stanowiąca średnio 60\% ogólnej wymiany państw Europy Środkowo-Wschodniej (należących do RWPG) wzajemna wymiana handlowa państw Rady gwałtownie się załamała. Spadek zarysował się już w 1989 r., lecz prawdziwy kataklizm nadszedł w latach 1990-1991, gdy eksport i import wewnątrz ugrupowania skurczyły się o ponad połowę. Były po temu dwa powody: rezygnacja z systemu rubla transferowego i przejście do cen bardziej zbliżonych do praktykowanych na rynkach światowych, co z jednej strony stwarzało naturalne preferencje dla eksporterów dysponujących lepszymi jakościowo i asortymentowo towarami, a z drugiej skutkowało chronicznym brakiem dewiz $^{49}$. Drugą, istotniejszą przyczyną zapaści była dotkliwa recesja w krajach regionu ${ }^{50}$.

${ }^{46}$ Commission des Communautés Européennes, Relations CE-Europe de l'Est, Bruksela, 7 grudnia 1990 r., X-ICC/A, HAEU, Deposit Pier Virgilio Dastoli, t. 100.

47 J. Rollo, 1985-1990: Towards a Comprehensive Eastern Policy for the Community, [w:] The New Eastern Europe: Western Responses, J. R o11 o, J. Blatt (red.), Royal Institute of International Affairs, 1990, s. 26.

${ }_{48} \mathrm{P}$. B e $\mathrm{n}$ a v i d e s S a l a s, Les mécanismes communautaires de la coopération Est-Ouest, [w:] J.-C. G a utro u, Les relations Communauté européenne - Europe de l'Est, Economica, Paryż 1991, s. 335.

${ }^{49}$ A. S li m, UE - Europe centrale et orientale. Entre concurrence et complémentarité, „Le courrier des pays de l'Est”, nr 1012, luty 2001, s. 34, zbliżone wartości procentowe oparte na danych Foreign Trade of the Republic of Bulgaria.

${ }^{50}$ Por.: J.-C. G a u t r o n, La problématique politique des relations entre la communauté européenne et l'Europe de l'Est, [w:] Les relations Communauté européenne - Europe de l'Est, Economica, Paryż, 1991, s. 4-9. 
Przykładowo, udział Węgier w eksporcie Polski wynosił w 1991 r. zaledwie 0,7\%, w imporcie zaś $0,9 \%$. Recesja ta była ceną za przekształcenia strukturalne, których pierwsza faza polegała na częściowej destrukcji niedostosowanego do nowych warunków aparatu wytwórczego ${ }^{51}$. Ze zjawiskiem tym łączył się spadek popytu wewnętrznego, co odbiło się na dynamice wymiany. Kolejną przyczyną było świadome przyjęcie nowych zasad polityki eksportowej i importowej, zakładających przeorientowanie handlu na Zachód.

\section{Ostatnie próby reform Rady}

Gorbaczowowskiej pieriestrojce towarzyszyły ostatnie próby reformowania podstaw RWPG. Dotyczyły one likwidacji nadmiernie rozrośniętej biurokracji, wprowadzenia swobodnego przepływu dóbr i towarów oraz wymienialności walut. Zarówno jednak „Kompleksowy program postępu naukowego i technicznego do roku 2000”, jak i przyjęta w 1988 r. w Pradze „Wspólna koncepcja międzynarodowego, socjalistycznego podziału pracy na lata 1991-2005" były inicjatywami skazanymi na klęskę. Na sesji Rady w Pradze w 1988 r. zaakceptowano radykalne w wydźwięku projekty tworzenia „socjalistycznego wspólnego rynku", którym międzynarodowe organizacje przyznały pozytywne oceny. ONZ poświęcił im osobny rozdział w swym raporcie na temat gospodarki światowej (World Economic Survey, 1989, ONZ) ${ }^{52}$. Niektóre reformatorskie rządy komunistyczne próbowały przekonywać do idei, która jeszcze kilka lat wcześniej mogła zostać uznana za herezję, czyli do tworzenia mniejszych ugrupowań pomiędzy krajami zdolnymi nawiązać prawdziwie rynkowe stosunki.

Podejście poszczególnych komunistycznych rządów państw Europy Środkowej do reformy RWPG było zróżnicowane. Coraz więcej krajów otwarcie podzielało opinię węgierskiej delegacji, wyrażoną na praskiej sesji Rady, że o ile wspólnota socjalistyczna zdołała znaleźć adekwatną odpowiedź na militarne wyzwania epoki, o tyle nie potrafiła stawić czoła wyzwaniom ekonomicznym i technologicznym ${ }^{53}$. Z deklaracji najważniejszych polityków węgierskich wynikało, że za priorytetowy kierunek obrano rozwijanie stosunków handlowych ze Wspólnotą Europejską. Niezależnie od ryzyka i kosztów związanych z samodzielną polityką, dla Węgier coraz bardziej oczywista była potrzeba jak najszybszej reorientacji i liberalizacji całości handlu zagranicznego, jako zasadniczych warunków powodzenia prowadzonej wówczas polityki reform. Budapeszt porzucił podejście wielostronne w ramach RWPG, wychodząc z założenia, że Rada w dotychczasowym kształcie stanowi hamulec dla gospodarki Węgier. Zdaniem węgierskich reformatorów, większe szanse miały próby dwustronnych inicjatyw (w koncepcji tej brano pod uwagę Polskę i Jugosławię).

Zmiany na Węgrzech w latach 80. dotknęły też sfery politycznej. Rząd węgierski, uczestnicząc w konferencjach międzynarodowych poświęconych prawom człowieka, stanął po stronie państw zachodnich. Niemniej następca Jánosa Kádára, Károly Grósz, nie

${ }^{51}$ Biała Księga, Polska-Unia Europejska, Wspólpraca w ramach Grupy Wyszehradzkiej, s. 13.

${ }^{52}$ L. C s a b a, Quo vadis COMECON? Le point de vue des petits pays de l'Europe de l'Est, „Le courrier des pays de 1'Est', nr 344, listopad 1989, s. 5.

53 Ibidem, s. 15. 
sądził, że poszerzenie obszaru swobód politycznych ma koniecznie przynieść stworzenie systemu wielopartyjnego w typie zachodnim. Inni prominentni działacze reformatorzy, Imre Poszgay i Rezső Nyers, przekonani, że reformy gospodarcze, niezależnie od ich radykalizmu, nie mogą się udać bez reform politycznych, wychwalali zalety austriackiego systemu wielopartyjnego ${ }^{54}$. Nyers uważał jednak za mrzonki marzenia o szybkim uczynieniu z Węgier kraju „zachodniego”: „Chcielibyśmy przyspieszyć wejście w życie układu z EWG, tak aby do 1995 r. zniknęły ekonomiczne i handlowe przeszkody, krępujące wciąż wymianę"55. Jego zdaniem, w nadchodzącej dekadzie można było sobie najwyżej wyobrazić pojawienie się Węgier prowadzących niezależną politykę zagraniczną, związanych przyjacielskimi więzami z ZSRR i Zachodem.

Przekonanie, że RWPG jest bezsilna w rozwiązywaniu problemów ekonomicznych było równie powszechne w Polsce. Przed 1985 r. Wojciech Jaruzelski bez powodzenia usiłował pójść drogą Kádára. Po zmianach w Biurze Politycznym PZPR, reprezentant reformatorskiego skrzydła partii, Mieczysław Rakowski, próbował jako premier wprowadzać w latach 1987 i 1988 ograniczone reformy, których celem miała być zmiana wizerunku polskiej gospodarki i zwiększenie udziału sektora prywatnego w PKB. Brak zadowalających efektów i przegrane referendum z końca 1987 r. dowiodły, że nie uda się w ten sposób wydobyć kraju z głębokiej recesji. Kryzys lat 80. sprawił, że zadłużenie Polski wobec pozostałych państw członkowskich RWPG stale rosło, osiągając wartość 2,4 miliarda dolarów ${ }^{56}$. Na początku 1989 r. Rakowski uznawał, że jedną z przeszkód na drodze integracji wschodnioeuropejskiej jest brak dostępu do nowoczesnych technologii, dodając: „wszyscy wiemy, gdzie ich szukać" ${ }^{57}$. Ostrożnie przyznawał zatem rację węgierskim politykom, twierdząc, że proces europeizacji społeczeństw i gospodarek państw bloku wschodniego jest nieodwracalny. Polscy eksperci dowodzili, że dopóki nie nastąpi przejście do reguł rynkowych i wymienialności gotówki na towar, zniesienie reguł administracyjnych przyspieszy dezintegrację, zamiast przynieść powrót do równowagi ${ }^{58}$.

Oficjalna linia Czechosłowacji była naturalnie wyważona. Husak oznajmił jeszcze w czerwcu 1985 r.: „Nie pójdziemy drogą prowadzącą w stronę rynku, ponieważ osłabiłoby to system własności kolektywnej i wiodącą rolę partii w ekonomii" ${ }^{59}$. W czechosłowackiej prasie nie brakowało wówczas zawoalowanych ataków na politykę Gorbaczowa. Tradycyjnie Praga stała na stanowisku, że uczestnictwo Czechosłowacji w RWPG, dla którego nie istnieje żadna alternatywa, ma charakter wybitnie polityczny. Dla rządzących w Pradze komunistów RWPG, niezależnie od jej wad, pozostawała jedynym źródłem zaopatrzenia w surowce i technologie, a ZSRR gwarantem postanowień poczdamskich. W późniejszym okresie do głosu zaczęli dochodzić reformatorzy, którzy w kwestii tworzenia wspólnego socjalistycznego rynku podkreślali konieczność uprzedniej likwidacji

${ }^{54}$ L. Duhame 1, Partisans de Gorbatchev et partisans du changement en Europe de l'Est 1985-89, „Etudes Internationales”, vol. XXI, nr 1, marzec 1990, s. 101.

55 R. Nye r s, Hongrie - la brèche, „Politique Internationale”, nr 45/1989, s. 259.

${ }_{56} \mathrm{Z}$ tego ponad połowę stanowił dług wobec ZSRR.

${ }_{57}$ M. Ra kow s ki, Pologne - l'ouverture, wywiad, „Politique Internationale”, nr 43, 1989, s. 213.

58 W. Herer i W. S a dow s ki, O gospodarce - dla dorostych, „Polityka”, 25.02.1989; S. B u k o w s k i, Rozwój powiązań kooperacyjnych Polski z krajami RWPG, „Sprawy Międzynarodowe”, 9/1988.

${ }^{59}$ L. D u ham e 1, Partisans de Gorbatchev... , s. 98. 
systemu cen, ustalanych odgórnie przez państwo, a także odpowiedniego zaopatrzenia rynków narodowych ${ }^{60}$.

Jak wiadomo, w dniach 9-10 stycznia 1990 r. dziesięciu szefów rządów RWPG stwierdziło, że organizacja poniosła porażkę, i w konsekwencji 28 czerwca 1991 r. nastąpiło jej rozwiązanie. Delegacja polska przeciwstawiła się wówczas utworzeniu na miejsce RWPG innej podobnej. 25 lutego 1991 r. za zgodą wszystkich stron, wyrażoną w protokole podpisanym na konferencji w Moskwie przez szefów sześciu państw członkowskich, Układ Warszawski rozwiązał swoje struktury wojskowe, a 1 kwietnia tegoż roku zakończył działalność także jego Komitet Polityczny. 1 lipca 1991 r. podpisany został protokół o całkowitym rozwiązaniu Układu Warszawskiego. W ten sposób zlikwidowano podporządkowane ZSRR struktury bloku wschodniego, oczyszczając pole dla nowych, wolnych od treści ideologicznych przyszłych powiązań traktatowych między państwami wchodzącymi w skład bloku.

\section{Bibliografia}

Archiwalia:

Historical Archives of the European Union, Florencja, Deposit Mouvement Européen.

Historical Archives of the European Union, Florencja, Deposit Walter Lipgens.

Monografie i artykuły:

Andreff W., Les échanges commerciaux CE-CAEM : L'Europe de l'Est entre l'espoir et la peur, [w:] „Regards sur l'actualité”, La Documentation française, Paris 1990.

Andreff W., Pays de la Communauté européenne et de l'Europe centrale depuis les années cinquante, [w:] L'Europe du centre. 50 années révolues, N. Bárdos-Féltoronyi, M. Sutton (red.), De Boeck Université, Bruxelles 1991.

Bo del D., La Communauté européenne et les pays de l'Est, Lausanne 1966.

Christine-Ryba B., L'Union européenne et l'Europe de l'Est. L'Evolution des relations de la Communauté - devenue Union européenne - avec l'Europe de l'Est et les perspectives d'avenir, „Revue du Marché Commun et de l'Union Européenne”, nr 382, listopad 1994.

Delwit P., Historique des relations entre la Communauté et les pays de l'Europe centrale et orientale, [w:] Un défi pour la communauté européenne. Les bouleversements à l'Est et au centre du continent, Etudes européennes, Université de Bruxelles, Bruxelles 1991.

Duhamel L., Partisans de Gorbatchev et partisans du changement en Europe de l'Est 1985-89, „Etudes Internationales”, vol. XXI, nr 1, marzec 1990.

Gautron J.-C., La problématique politique des relations entre la communauté européenne et l'Europe de l'Est, [w:] Les relations Communauté européenne - Europe de l'Est, Economica, Paris 1991.

Gołembski F., Polska a zmiany zachodzace w państwach Europy Środkowo-Wschodniej i Poludniowo-Wschodniej, PISM, Warszawa 1990.

Herer W., Sadowski W., O gospodarce - dla dorostych, „Polityka”, 25.02.1989.

Kawan L., Conséquences des modifications survenues en Hongrie sur les relations avec la Communauté européenne, [w:] Un défi pour la Communauté européenne. Les bouleversements à l'Est et au centre du continent, Editions de l'Université de Bruxelles, Bruxelles 1991.

Łaptos J., Europa jedna czy dwie? Projekty i koncepcje integracji europejskiej w latach 1944-1950, Oficyna Abrys, Kraków 1994.

${ }^{60}$ L. Cs a b a, Quo vadis COMECON? Le point de vue des petits pays de l'Europe de l'Est..., s. 12. 
Lavigne M., Les relations économiques Est-Ouest, Presses Universitaires de France, Paryż 1979.

Matera R., Stosunek Grupy Siedmiu do Europy Środkowej i Wschodniej w okresie zimnej wojny oraz w czasie transformacji ustrojowej, „Studia Europejskie”, 2008/1.

Nyers R., Hongrie - la brèche, „Politique Internationale”, nr 45/1989.

Płonka B., Polityka Unii Europejskiej wobec Europy Środkowej, wyd. UJ, Kraków 2003.

Prażuch W., Środkowoeuropejska emigracja polityczna i jej wizje integracji kontynentu po upadku komunizmu w świetle dokumentów z Archiwów Historycznych Unii Europejskiej, [w:] A. Kozera, W. Prażuch, P. Szyja (red.), Polska, Europa Środkowa, Europa Zjednoczona: księga jubileuszowa dedykowana profesorowi Józefowi Łaptosowi, Wyd. Uniwersytetu Pedagogicznego, Kraków 2014.

Rakowski M., Pologne - l'ouverture, wywiad, „Politique Internationale”, nr 43, 1989.

Rollo J., 1985-1990: Towards a Comprehensive Eastern Policy for the Community, [w:] The New Eastern Europe: Western Responses, J. Rollo, J. Blatt (red.), Royal Institute of International Affairs, 1990.

Sidjanski D., Le dialogue des deux Europes et le rôle de la Communauté européenne, [w:] Un défi pour la Communauté européenne. Les bouleversements à l'Est et au Sud du continent, Université de Bruxelles, Bruxelles 1991.

Slim A., UE - Europe centrale et orientale. Entre concurrence et complémentarité, „Le courrier des pays de l'Est", nr 1012, luty 2001.

Soulier G., L'Europe, Armand Colin, Paryż 1994.

Vučković Z., Kontakty gospodarcze wspólnot europejskich z SFR Jugosławia (1968-1991), „Zeszyty Naukowe Towarzystwa Doktorantów UJ", Nauki Społeczne, nr 6 (1/2013).

\section{Wojciech Prażuch}

\section{Central European States and Their Attempts to Get Closer to EEC}

\section{Summary}

During the Cold War, economic relations of the European Communities and Central European states of the Council for Mutual Economic Aid were highly unstable. It was due to lack of institutional frameworks between integration structures of the two parts of the divided continent and the growing protectionism of EEC developing its common trade and agricultural policies. However, the doctrinal crisis of communism and gradual normalisation of East-West relations after concluding the Helsinki Final Act was for some Central European countries an opportunity to make bolder attempts at circumventing the informal prohibition of contacts with Brussels resulting from Soviet political imperatives. The paper is an attempt to demonstrate that it was to some extent in line with the statements of the representatives of political emigrants from Central Europe. They argued that taking advantage of natural interest differences occurring in relations between the Soviet Union and its satellite countries and cautious support of contacts, including economic contact, would lead to disintegration of the eastern monolith and expansion of the "freedom area", paving the way for future unification of the continent.

Key words: Central Europe, political emigration, East-West relations, European integration. 